\author{
E.S. Madiyarova ${ }^{1,}$, L.B.Gabdullina ${ }^{2}$, A.Zh. Zeynullina ${ }^{3}$ \\ ${ }^{I}$ D. Serikbayev East Kazakhstan Technical University, Ust-Kamenogorsk, Kazakhstan \\ ${ }^{2}$ l.N.Gumilyov eurasian national university, Nur-Sultan, Kazakhstan \\ ${ }^{3}$ Shakarim University, Semey, Kazakhstan \\ lemadiyarova@mail.ru, lazzat_0610@list.ru,3aigul-zeinullina@mail.ru \\ ${ }^{1}$ https://orcid.org/0000-0002-2944-6968, ${ }^{2}$ https://orcid.org/0000-0002-9219-1603, \\ ${ }^{3}$ https://orcid.org/0000-0002-4787-4966 \\ ${ }^{I}$ Scopus Author ID: 56712848600 \\ ${ }^{1}$ Researcher ID: AAF-6844-2019
}

\title{
Current State of the East Kazakhstan Transportation and Logistics Complex
}

\begin{abstract}
Object: study of the current state and development priorities of the transport and logistics complex of the East Kazakhstan region.

Methods: the theoretical basis of the research is the works of domestic and foreign scientists-economists on the development of the transport and logistics complex, legislative and regulatory acts of the Republic of Kazakhstan. The information base of the research is based on the data of the statistics Committee of the Ministry of economy of the Republic of Kazakhstan and the results of the authors' research. The methodological basis of the research is a systematic approach, abstract-logical, economic-statistical, monographic methods of studying economic processes.

Findings: this article presents the results of the analysis of the socio-economic development of the East Kazakhstan region and the transport complex of the region. The analysis revealed the main problems of development of the transport and logistics complex of the East Kazakhstan region, including limited logistics and technical capabilities of carriers, underdeveloped infrastructure, lack of developed transport and logistics centers, warehouses and terminals, lack of qualified specialists, low quality of service.

Conclusions: the main factors affecting the transport and logistics complex of the East Kazakhstan region are studied. As a result of the research, priority measures for the development of the transport and logistics complex of the region are proposed, including modernization of transport logistics, construction of large warehouse complexes and improvement of production infrastructure, creation of an effective network of transport communications and use of innovative technologies in the transport and logistics complex.
\end{abstract}

Keywords: transport complex, logistics, macroregion, regional economy, transport network, transport hubs, cargo terminals, transit, foreign trade, cargo and passenger transportation.

\section{Introduction}

The transportation and logistics complex of the region implies the interconnected functioning of the region's transport complex and the regional logistics system, which are dependent on and interact in the performance of transportation. The state of functioning and development of the complex is of global importance in the development of the national economy of any region. Therefore, the study and research paper on this issue are quite relevant. The purpose of this research paper is to study the current state and identify major problems of transportation and logistics complex of the East Kazakhstan. The research objectives were achieved due to analysis of key indicators of socio-economic and territorial development of the East Kazakhstan region as a whole, and analysis of statistical data separately on the transportation and logistics complex of the region. Moreover, regional and state programs and legislative acts were studied. Based on the conducted analytical review, priorities and problems of development of transport and logistic complex of the region have been revealed.

\section{Literature Review}

This paper is linked to a broad empirical literature explaining the theoretical basis of the issue. A large number of foreign scientists are engaged in the problems of transport and transport logistics, including T.Aized, J.S. Srai (Aized, Srai, 2020), J. Blyde, D. Molina (Blyde, Molina, 2015), A. Diogo, P. Lima, F.W. Mascarenhas, E.M. Frazzon (Diogo et al., 2015), S.M. Rezer, T.A. Prokofiev, C.C. Goncharenko

\footnotetext{
"Corresponding author.

E-mail: emadiyarova@mail.ru
} 
(Rezer et al., 2010), V.I. Apattsev, S.B. Levin, V.M. Nikolashin (Apattsev et al., 2003), V.I. Sergeev (Sergeev, 2015).

In the study of issues related to the national transport industry development, such economic scientists took part: O. Sabden, Zh.S. Raimbekov (Sabden, Raimbekov, 2010), B.U. Syzdykpaeva (Raimbekov, Syzdykbaeva, 2019), V. Mozharova (Mozharova, 2011), T.B. Suleimenov, M.I. Arpabekov, Zh.M. Kuanyshbaev (Suleimenov et al., 2015), A.S. Koichubaev (Koichubaev, 2013).

\section{Methods}

The research methodology is a set of methods, mechanisms, principles and measures for the development of the transport and logistics complex of the East Kazakhstan region. The study was conducted using General methods used in Economics, using a systematic approach that provides the necessary depth of study of the scientific problem. The sources of the research are theoretical and analytical articles, works of Kazakhstani and foreign authors, which address the problems of transport and transport logistics.

When writing the article, the authors used the following general scientific methods: empiricaltheoretical analysis, statistical and normative analysis, synthesis, analogy, generalization, as well as methods of scientific knowledge. Methods of quantitative analysis and synthesis, methods of statistical groupings and dynamic series were used in data processing. These methods made it possible to ensure the reliability of the analysis and the validity of the conclusions.

Information base of research made up of legislative and other normative acts of the Republic of Kazakhstan, statistics Agency of the Republic of Kazakhstan on statistics, analytical materials, materials of scientific economic literature and periodicals, materials of scientific-practical conferences, electronic resources.

\section{Findings}

East Kazakhstan is the developed industrial-agrarian region of the country and is a part (together with Pavlodar and Karaganda regions) of the Central Eastern macro-region with the Hub center in UstKamenogorsk city. According to the Committee of Statistics of the Ministry of National Economy of the Republic of Kazakhstan data, Gross Regional Product (GRP) for 2019 amounted to 4088.8 billion Kazakhstani tenge, with an increase of 132.1 percent compared to 2017 (3 174.8 billion Kazakhstani tenge). (Kólik statistikasy, 2019).

Among other regions by this indicator, the East Kazakhstan is in the 9th place with a share of 5.9 percent of the total GDP of Kazakhstan (68 956.4 billion Kazakhstani tenge). By GRP per capita, the region ranks 9th place in Kazakhstan. GRP per capita dynamics of the region is to a great extent conditioned by the maintenance of positive growth rates in the main industries. The share of goods production has reached 46.0 percent, the share of services -54 percent. The share of industry in the regional economy structure is also quite significant: about 35.5 percent in GRP.

In 2019, the volume of industrial production was 2141.5 billion Kazakhstani tenge, compared to 2017 (1 581.5 billion Kazakhstani tenge), the growth rate was 135.4 percent. The share of the region in the national industrial production volume is 7.3 percent. Agriculture is one of the basic branch of the local economy for 14 out of 15 areas (except for the Altay area). The share of agriculture in the GRP of the region is 8.5 percent. Gross output of agriculture in 2019 amounted to 594.8 billion Kazakhstani tenge, the growth rate of the industry compared to 2017 (472.0 billion Kazakhstani tenge) was 126 percent. The region share in the volume of the national GDP of agriculture is 11.4 percent. The volume of investments in fixed capital from 2017 (436.1 billion Kazakhstani tenge) increased by 142.0 percent and in 2019 amounted to 649.3 billion Kazakhstani tenge. The retail trade volume in 2019 amounted to 1001.1 billion Kazakhstani tenge, compared to 2017 (787.6 billion Kazakhstani tenge), the growth rate was 127.1 percent.

East Kazakhstan is distinguished by developed industrial infrastructure, which is represented by all main modes of transport: railway, aviation, water, and automobile. The regional transportation complex has a crucial role to play in the implementation of inter-economic and interstate relations. Road transport plays an important role in the development of market infrastructure, expansion of domestic and foreign trade, and the status of the main carrier belongs to this type of transport. The following main transportation hubs should be distinguished in this region: Ust-Kamenogorsk, Semey, Ayagoz, and Sharsk.

The Semey transportation hub is the main one in the East Kazakhstan region, as large transport highways, both the railway and automobile, pass through it. It connects both intra-Republic and inter-Republic highways. The Ust-Kamenogorsk transport hub connects the region's districts. Ayagoz transport hub is a 
link between the largest highways of the republic. By this time, the Sharsk transport hub is not as important in our region as the Semey one, but its importance is expected to increase in the near future.

Rail transport. Railroads connect the regional center with the cities of Altay, Ridder, Semey, Ayagoz, Shar and Shemonaikha. There are also railway lines leading outside the region: "Semey - Lokot", "Semey - Almaty", "Semey - Pavlodar", "Zashchita - Lokot", "Zashchita - Altay", "Zashchita - Leninogorsk" and "Zashchita - Shar". The extended length of the main railroads in the region is $1209 \mathrm{~km}$, which is 7.3 percent of the total length of the national railroads. The density of the region's railroads is $4.1 \mathrm{~km}$ per 1 000 square kilometer, which is $1.4 \mathrm{~km}$ lower than the national average (in Kazakhstan $-5.5 \mathrm{~km}$ per 1000 square kilometer). Railway tracks in the region are mainly single-track $(10.5 \mathrm{~km}$ from common tracks double-track), lines are not electrified. There are 298 settlements of the region having access to the railway (radius up to $50 \mathrm{~km}$ ), which is 42 percent. There is no railway service in Abaj, Beskaragaj, Zajsan, KatonKaragaj, Kokpeky, Kurchum, Tarbagataj, and Urdzhar areas.

In the region there are two branches of railroads, these are branches of the "National Company "Kazakhstan Temir Zholy" - "Semey Branch of The Road" JSC in the city of Semey and East Kazakhstan branch of the railway (so-called "Zashchita"). Transportation of passengers and luggage by rail is carried out in the following directions: "Ust-Kamenogorsk - Almaty", "Ridder - Nur-Sultan" (with one trailer car to Moscow), "Tomsk - Ridder", "Semey - Kyzylorda", and transit: "Novokuznetsk - Semey - Bishkek"; "Novosibirsk - Semey - Almaty"; "Novosibirsk - Semey - Tashkent"; "Pavlodar - Semey - Almaty"; "Pavlodar - Semey - Karaganda", as well as inter-district communications "Zashchita - Zyryanovsk" and "Zashchita - Leninogorsk".

Aircraft. There are 4 airports in the region. 2 airports are allowed to serve international flights (Ust-Kamenogorsk, Semey) and the other two serve only local airlines (Zajsan, Urdzhar). UstKamenogorsk airport is categorized by ICAO standards as Category I. Airport Semey ("Semey International Airport" LLP) serves the following routes: Almaty, Nur-Sultan, Ust-Kamenogorsk, Urdzhar. Since 2016, as part of the Nurlyzhol State Program, the runway, taxiways and airport terminal have been reconstructed. Ust-Kamenogorsk airport serves the following routes: Almaty, Nur-Sultan, Karaganda, Moscow, Novosibirsk Semey, Urdzhar, Zajsan. In 2017 the arrival terminal for 200 passengers per hour was put into operation. The issue of reconstruction of the airport complex is under study. It is also planned to complete the reconstruction of the airport of Semey, which will increase the number of flights and passengers served, improve flight safety.

Waterway transport. The main navigable highway of inland waterways of the East Kazakhstan region is the Irtysh River, which flows from the border of the People's Republic of China to the border of the Russian Federation. The length of the river on the territory of the Republic of Kazakhstan - $1698 \mathrm{~km}$, including the territory of the region $-1116 \mathrm{~km}$. By now in the region, there are three shipping sluices, two river cargo ports: a cargo port of "Irtysh-Trans" LLP and a river port in Semey. There are two lines of ferry transportation of passengers in the area of Kaznakovka and Ulken Naryn villages, which are carried out by private organizations. The ferry crossings provide residents of Kurchum and Katon-Karagaj areas with transport services.

Road and municipal electrically driven transport. The region has the longest network of public highways in all country $-11,997.6 \mathrm{~km}$, including: of national importance $-3,414 \mathrm{~km}$ (28.7 percent), of regional importance $-3186 \mathrm{~km}$ (26.6 percent), of regional importance - $5397.6 \mathrm{~km}$ (44.7 percent), of which 7 $057.4 \mathrm{~km}$ are paved, $4,167.65 \mathrm{~km}$ are gravel paved and $772.5 \mathrm{~km}$ are unpaved, with 514 bridge structures and 6,653 culverts, the density of paved roads is $36.6 \mathrm{~km}$ per thousand kilometers.

According to the Kazakhstan Ministry of Internal Affairs in 2018, the number of buses in the region amounted to 6182 units, 3627 of which are privately owned. In 2018, the number of registered cars amounted to only 301.4 thousand units, of which 288.3 thousand units were in private ownership, i.e. provision of the population with passenger car transport is 21.8 units per 100 people. The total number of trucks in 2018 amounted to 32058 units, of which about 70 percent are owned by private individuals.

The main transit corridor passing through the territory of the East Kazakhstan region is a M-38 Highway "Omsk - Majkapchagaj" (republican importance), exit to the 2nd Trans European Corridor (including People's Republic of China), the total length of the road is $1099 \mathrm{~km}$. East Kazakhstan is connected with Almaty, Karaganda, Pavlodar regions by highways of republican importance "Almaty - UstKamenogorsk", "Karaganda - Ayagoz - Bogas", "Omsk - Majkapchagaj". Besides, the region is connect- 
ed with the Chinese road ("Taskesken - Bahty") and the Russian road ("Ust-Kamenogorsk - Shemonaikha - State Border of the Russian Federation").

Transportation of passengers by road is carried out on 326 regular routes. These include international routes (18), intercity intraregional routes (76), intraregional routes (51), intra-settlement routes (14), and intra-city routes (145). In nine areas, roads are the only means of communication. The most favorable situation with the route traffic coverage is observed in Shemonaiha and Boroduliha areas. The settlements of Abaj, Ayagoz, Zharmin and Katon-Karagaj areas are the least provided with regular route communication. The main reasons for the absence of road transport in settlements are the lack of a roadbed, unprofitability of transportation, due to the small population (less than 100 people), as well as the implementation of transportation by private passenger cars. To improve the work in this direction, the system of electronic sale of tickets for long-distance and international routes through terminals, as well as through payment cards sold through the Internet, work is being done to equip buses with the global positioning system. In 2018, 62.3 billion Kazakhstani tenge was allocated from all sources for road repairs of the region's roads and $391 \mathrm{~km}$ of roads were repaired. As a result, the share of roads in good and satisfactory condition increased to 78 percent.

In the city of Ust-Kamenogorsk, there is a streetcar service, the length of which in the two-track calculation, in 2018 amounted to $14.5 \mathrm{~km}$, the total number of rolling stock streetcar park - 54 units.

The largest volume of cargo and passenger transportation is by road and rail. Road transport carries 89.9 percent of cargoes, railroad transport -10 percent. The volume of passenger transportation by road is 96.2 percent, railroad -2.5 percent, aviation -1.3 percent.

The main objective of transport is timely, quality, and full satisfaction of the needs of the economy and population in transportation. According to the Committee on Statistics of the Ministry of Economics of the Republic of Kazakhstan data, in the last three years, there is a tendency of growth of the main indicators of the transport complex of the region (Table 1).

Table 1. Dynamics of the major indicators of the East Kazakhstan transportation and logistics complex for the period from 2017 to 2019

\begin{tabular}{|c|c|c|c|c|c|}
\hline No. & Indicator & 2017 & 2018 & 2019 & $\begin{array}{l}2019 \text { to } \\
2017, \%\end{array}$ \\
\hline 1 & $\begin{array}{l}\text { Gross transport (warehousing) services, } \\
\text { bln. KZT }\end{array}$ & 411,4 & 437,4 & 460,1 & 111,8 \\
\hline 2 & Share of transport services in GRP, $\%$ & 10,4 & 9,9 & 8,8 & 84,6 \\
\hline 3 & Passengers transported, mln. people & 1709,2 & 1714,9 & 1716,3 & 100,4 \\
\hline 4 & The passenger turnover, mln. passenger-km & 22272,4 & 22762,4 & 24449,8 & 109,7 \\
\hline 5 & $\begin{array}{l}\text { Transported cargo, baggage, cargo baggage, mln. } \\
\text { tons }\end{array}$ & 600,8 & 631,5 & 662,2 & 110,2 \\
\hline 6 & Cargo turnover, bln. tonne-km & 16,1 & 16,1 & 16,2 & 100,6 \\
\hline 7 & $\begin{array}{l}\text { Tariff index for the carriage of goods by all modes } \\
\text { of transport }\end{array}$ & 103,1 & 101,8 & 103,3 & 100,1 \\
\hline
\end{tabular}

Thus, according to preliminary data, 1716.3 million passengers were transported by all modes of transport in 2019, passenger turnover was 24449.8 million passenger-km, which is 9.7 percent more than in 2017. The volume of transported cargoes amounted to 662.2 million tons, cargo turnover amounted to 16.2 billion tonne-km, as compared to 2017 the volume of cargo transportation increased by 10.2 percent, and cargo turnover by 0.6 percent. Gross output of transport services of the region in 2019 amounted to 460.1 billion Kazakhstani tenge, compared to 2017 growth is 48.7 billion Kazakhstani tenge or 11.8 percent. The share of transport services in GRP was 8.8 percent, compared to 2017, there is a decrease of this indicator by 15.4 percent. The index of tariffs on carriage of goods by all types of transport is growing by 0.1 percent. Average range of transportation of 1 ton of cargo and average distance of transportation of 1 passenger is $25.5 \mathrm{~km}$ and $13.3 \mathrm{~km}$ respectively.

Investments in fixed assets of the region's transportation and logistics industry are constantly growing. Thus, in 2019 the volume of investments into fixed assets of transport and warehousing amounted to 70 693.3 million tons, as compared to 2017 it increased by 23711.5 million tons (50.4 percent). In the total vol- 
ume of investments in the region (619 387.8 million Kazakhstani tenge), the share of the industry "Transport and Storage" was 11.4 percent, which exceeds several times the investments in agriculture, construction, and trade (Table 2).

Table 2. Structure of investments in fixed capital by main types of economic activities for the period from 2017 to 2019

\begin{tabular}{|c|c|c|c|c|}
\hline No. & Name & 2017 & 2018 & 2019 \\
\hline 1 & Total by region, mln. KZT & 436107,0 & 488518,5 & 619387,8 \\
\hline & Including: & & & \\
\hline 2 & Agriculture, forestry and fishery & 18364,3 & 26938,5 & 30863,7 \\
\hline 3 & Industry & 268353,0 & 289349,6 & 391539,0 \\
\hline 4 & Building and construction & 3857,4 & 7250,6 & 10052,0 \\
\hline 5 & Trade, repair of cars and motorcycles & 6583,1 & 13756,1 & 9714,3 \\
\hline 6 & Transportation and warehousing & 46981,8 & 58141,4 & 70693,3 \\
\hline 7 & Accommodation and public catering services & 8241,6 & 3249,8 & 3069,1 \\
\hline 8 & Financial and insurance activities & 1298,9 & 997,0 & 3794,2 \\
\hline 9 & Communication & 1805,5 & 2977,1 & 1656,8 \\
\hline
\end{tabular}

The transport industry is one of the profitable sectors of the economy. According to the statistical data, for the last three years, there is a tendency of growth of incomes on the main types of transport and warehousing activities in the region.

According to preliminary data, in 2019, industry revenues amounted to 37278.8 million Kazakhstani tenge, compared to 2017, revenues increased by 36.8 percent (10 043.8 million Kazakhstani tenge), including revenues from passenger transportation increased by 33.3 percent $(750.2$ million Kazakhstani tenge), and transportation of cargo, luggage and cargo luggage by 75.1 percent (8 666 million Kazakhstani tenge).

In 2019, compared to 2017, revenues from vehicle rental also increased by 20.7 percent, revenues from non-transportation activities by 44.2 percent, and auxiliary transport activities by 2.8 percent (Table 3).

Table 3. Dynamics of transport industry income for the period from 2017 to 2019, $\mathrm{mln}$. KZT

\begin{tabular}{|c|c|c|c|c|c|}
\hline No. & Indicator & 2017 & 2018 & 2019 & $\begin{array}{l}2019 \text { to } \\
2017, \%\end{array}$ \\
\hline 1 & Total income & 27235,0 & 34843,1 & 37278,8 & 136,8 \\
\hline 2 & passenger transportation & 2250,7 & $\mathrm{x}$ & 3000,9 & 133,3 \\
\hline 3 & $\begin{array}{l}\text { freight forwarding, luggage and cargo } \\
\text { transportation }\end{array}$ & 11538,9 & 16973,4 & 20204,9 & 175,1 \\
\hline 4 & transport support activities & 12055,4 & 14095,4 & 12394,6 & 102.8 \\
\hline 5 & rental of vehicles with a driver (crew) & 1390,0 & 1550,2 & 1678,4 & 120,7 \\
\hline 6 & income from non-transportation activities & 5122,7 & 2629,3 & 7390,8 & 144,2 \\
\hline
\end{tabular}

According to preliminary data, in 2019 the number of employees in the "Transport and Warehousing" industry was 43.9 thousand people, that is about 6.4 percent of the total number of employees in the region (681.0 thousand people). Thus, compared to 2017 there is a slight increase (about 1 percent). The level of employment in the transport sector is one of the highest. The average monthly nominal salary by the "Transport and Storage" economic activity per employee in 2019 was 174621 thousand Kazakhstani tenge, this figure is more than almost 25 percent than in 2017. The average salary per employee in this industry was 8.6 percent higher than the average monthly nominal salary in the region as a whole (160 711 Kazakhstani tenge).

Also, in the field of transport and warehousing, the level of average monthly nominal wages is higher than in agriculture, forestry and fisheries, accommodation and catering services and trade, repair of cars and motorcycles. 
Table 4. Number of employees and average monthly nominal salary, by economic sector

\begin{tabular}{|c|c|c|c|c|c|c|c|}
\hline \multirow[t]{2}{*}{ No. } & \multirow[t]{2}{*}{ Name } & \multicolumn{3}{|c|}{$\begin{array}{l}\text { Number of employees, } \\
\text { ths. people }\end{array}$} & \multicolumn{3}{|c|}{$\begin{array}{l}\text { Average monthly nominal } \\
\text { salary, KZT }\end{array}$} \\
\hline & & 2017 & 2018 & 2019 & 2017 & 2018 & 2019 \\
\hline 1 & Total by region & 687,6 & 679,0 & 681,0 & 125911 & 140126 & 160711 \\
\hline & Including: & & & & & & \\
\hline 2 & Agriculture, forestry and fishery & 105,5 & 104,9 & 103,1 & 93200 & 104421 & 126773 \\
\hline 3 & Industry & 111,2 & 112,3 & 110,8 & 178254 & 205905 & 228740 \\
\hline 4 & Building and construction & 34,4 & 34,4 & 33,2 & 130641 & 153166 & 182399 \\
\hline 5 & Trade, repair of cars and motorcycles & 120,9 & 120,9 & 122,7 & 123745 & 142178 & 161250 \\
\hline 6 & Transportation and warehousing & 42,7 & 42,7 & 43,9 & 139711 & 163348 & 174621 \\
\hline 7 & $\begin{array}{l}\text { Accommodation and public catering } \\
\text { services }\end{array}$ & 29,5 & 20,5 & 15,8 & 85462 & 101054 & 110125 \\
\hline 8 & Financial and insurance activities & 8,5 & 6,8 & 12,5 & 178713 & 195144 & 211565 \\
\hline 9 & Communication & 15,2 & 14,3 & 9,5 & 161068 & 167609 & 187895 \\
\hline
\end{tabular}

The movement of goods and cargo is associated with the need to perform certain operations, the socalled transport services. Forwarding companies are engaged in organizing the transportation of goods from client to consignee by different modes of transport: road, rail, sea, aviation. Besides, freight forwarding companies carry out storage and storage of goods, insurance, as well as informing the client about all points of cargo location. There is an intensive form of the market of transport-forwarding and customs warehousing services in the region. A network of customs warehouses, intermediary, and commercial structures to provide warehousing, transportation, and freight forwarding services is registered and operates. According to the "Kedentransservice" data, the following cargo terminals operate in the region (Table 5).

Table 5. Cargo terminals in East Kazakhstan region

\begin{tabular}{|c|c|c|c|}
\hline No. & Location & Existing area & Activity \\
\hline 1 & Semey & $\begin{array}{l}\text { The total area is } 38.4 \text { hectares. } \\
\text { The closed warehouse PVC area of } 2124 \text { square meters, } \\
\text { actually used } 1200 \text { square meters. } \\
\text { The load of the terminal is between } 30 \text { and } 40 \text { percent. } \\
\text { There are } 8 \text { access roads total long (useful) } 6557.71 \text { meters. } \\
\text { The capacity of the loading and unloading front is } 451 \text { con- } \\
\text { ventional cars. }\end{array}$ & $\begin{array}{l}\text { Medium-tonnage, large- } \\
\text { tonnage containers, } \\
\text { heavy cargoes, trucks } \\
\text { and cars, caterpillar ve- } \\
\text { hicles, dry cargoes. } \\
\text { All type of cargo, except } \\
\text { for dangerous and explo- } \\
\text { sive ones. }\end{array}$ \\
\hline 2 & Ust-Kamenogorsk & $\begin{array}{l}\text { The total area is } 18 \text { hectares. } \\
\text { The closed warehouse } 1802 \text { square meters of PVC and } \\
\text { fenced outdoor area ZTK of } 1000 \text { square meters. } \\
\text { There are } 8 \text { access roads with a total length (useful) of } 3 \\
105.3 \text { meters. } \\
\text { The capacity of the loading and unloading front is } 69 \text { con- } \\
\text { ventional cars. }\end{array}$ & $\begin{array}{l}\text { Medium-tonnage, large- } \\
\text { tonnage containers, } \\
\text { heavy cargoes, trucks } \\
\text { and cars, tracked vehi- } \\
\text { cles. }\end{array}$ \\
\hline
\end{tabular}

There are six customs checkpoints in the region: "Oskemen-Center of Customs Clearance", "Auezhaj Oskemen", "Bahty", "Majkapchagaj", and crossing points: "Zajsan", "Majkapchagaj", and "Semey". The largest and key international checkpoints in eastern Kazakhstan, through which the main passenger and transport flows are carried out, are "Bahty" and "Majkapchagaj" (Transportnaya otrasl' Kazahstana, 2019). The prospects for developing the potential of the region's transport and logistics complex directly depend on the pace of development of the region as a whole and, in particular, on the development of trade and the volume of investments in priority sectors, including transit traffic.

The development of the transportation and logistics complex of the East Kazakhstan region is implemented within the framework of sectoral and intersectoral programs adopted in the Republic of Kazakhstan. The most significant inter-sectoral programs aimed at realizing the transport and transit potential of Kazakh- 
stan are the State Program for Development and Integration of Infrastructure of the Transport System of the Republic of Kazakhstan until 2020, which was preceded by the Program for Development of Transit and Transportation Potential of the Republic of Kazakhstan for the period from 2004 to 2006, the State Program for Development of Transport Infrastructure in the Republic of Kazakhstan for the period from 2010 to 2014 and the "Nurly Zhol" State Program of Infrastructure Development for the period from 2015 to 2019. Currently, the "Nurly Zhol" State Program of Infrastructure Development for the period from 2020 to 2025 is being implemented. Within the framework of the state programs on the development of transport and transit potential, about 7930 billion tenge were allocated. In the framework of the "Nurly Zhol" State Program, it was supposed to finance in the amount of 5539 billion tenge (Gosudarstvennaya programma razvitiya infrastruktury "Nurly zhol" na 2020-2025 gody, 2020).

The "Nurly Zhol" State Program assumes the performance of the main serious tasks for the national development of transport and logistics infrastructure, such as the development of transport and logistics infrastructure between the regions of Kazakhstan, the formation of macro-regions on the principle of hubs associated with the city of Nur-Sultan and between the main roads, rails and airlines on the beam principle. Moreover, the task was set to implement 7 major road projects, which will open up opportunities for the wide use of transport lines within the country. At the moment, work is continuing to improve legislation in the transport industry. Kazakhstan plans to become a Eurasian transport and logistics and business hub - such an idea was put forward by the Head of State in the context of the revival of the Silk Road.

Following the order of the President of the Republic of Kazakhstan based on "NC KTZH" JSC was established "KTZExpress" JSC, which today is a logistics operator for the creation of transport and logistics centers (TLC) in the country. According to "KTZExpress" JSC in Ust-Kamenogorsk, it is planned to build an "A" class TLC at the expense of "NC KTZ" JSC and private investments. The national transport and logistics center provides strict requirements for the architecture of the warehouse, the width of the flights, the height of the storage shelves, the temperature regime, the location of warehouses on the principle of transport multimodality, plus stringent requirements for safety, including fire safety. The feasibility study of the project has been developed (Razvitiye seti transportno-logisticheskikh tsentrov Kazakhstana, 2017).

As of today, the first stage of the "B+" class TLC (so-called "Severnoe") construction has been completed in Semey. This shopping mall will provide the following services: loading and unloading operations, cargo handling, packing, billing, warehousing, renting of retail space. It is planned to service the cargo in the following directions: China-Russia transit, China-Kazakhstan import, Kazakhstan-Russia export. It is planned to create a production base for storage, packaging, and processing of products in the city of Semey, with a production capacity of 450 thousand tons per year, an area of 30 thousand square meters. The total volume of expected investment will amount 32.8 million USD (Prognoz sotsial'no-ekonomicheskogo razvitiya Vostochno-Kazakhstanskoy oblasti na 2017-2021, 2017).

To ensure year-round uninterrupted traffic between Zharmin, Katon-Karagajs, Kurchum, Kokpekty, Zajsan and Altaj areas of the East Kazakhstan region, it is planned to implement the "Construction and Operation of The Bridge Crossing of The Bukhtarma Reservoir in Kurchum District" project. This project envisages the construction of an overpass (bridge crossing). The length of the planned 2 lane highway bridge is 1300 meters, width 12.2 meters. Design and budget documentation (DBD) was also developed, construction cost -37.2 billion Kazakhstani tenge. In the implementation of this project will be possible to cross the Bukhtarma Reservoir at any time of year, will reduce travel time, besides, the safety of vehicular traffic in winter.

In 2018, 62.3 billion Kazakhstani tenge was allocated from all sources for road repairs of the region's roads and $391 \mathrm{~km}$ of roads were repaired. As a result, the share of roads in good and satisfactory condition increased to 78 percent. It is planned to increase the share of highways in "good" and "satisfactory" condition up to 81 percent by 2021 . The following local activities were carried out to develop transport infrastructure:

- reconstruction of the Semey Airport (10.7 billion Kazakhstani tenge);

- reconstruction of the airport terminal complex in Ust-Kamenogorsk for 0.5 billion Kazakhstani tenge (put into operation the arrival terminal);

- construction of a bus terminal in Boroduliha village (20 million Kazakhstani tenge);

- construction of 12 passenger service points in 4 areas of the eastern Kazakhstan (Glubokoe, Urdzhar, Tarbagataj, Shemonaiha); 
- DBD for reconstruction of the runway of the airport in Ust-Kamenogorsk (10.3 billion Kazakhstani tenge);

- DBD for reconstruction of the airport in Urdzhar village (4.7 billion Kazakhstani tenge).

Besides, 8 projects on reconstruction on the roads of national importance are being implemented. In 2018-2019, 61.5 billion Kazakhstani tenge were allocated for these tasks (in 2018 - 14.5 billion Kazakhstani tenge, in $2019-47.0$ billion Kazakhstani tenge). It is expected that further development of transport infrastructure will be achieved through the implementation of the project for the construction of the "Nur-Sultan Pavlodar - Kalbatau - Ust-Kamenogorsk" motor corridor and the completion of work in the directions "Taskesken - Bahty" and "Omsk - Majkapchagaj". It is planned to ensure quality transport accessibility of customs checkpoints (Majkapchagaj, Bahty), territories with undeveloped mineral deposits, as well as territories with tourist potential like Alakol, Zajsan, Katon-Karachi, and others. Based on the UstKamenogorsk city hub there will be formed a single system of Central Eastern macro-region for delivery and storage of goods from China to Kazakhstan, as well as countries of Eastern and Western Europe (Sushchestvuyushchie na territorii RK gruzovye terminaly AO Kedentransservis, 2019).

The conducted analysis testifies to the stable operation of the region's transport industry, and the growth of its main indicators is observed. Stabilization of the economic situation, development of private entrepreneurship in the industry allows increasing the volumes of transportation. Favorable geographical location and sufficiently developed transport and logistics complex of the East Kazakhstan region provides an opportunity to create in the regional transportation and logistics system on the way from China to the Russian Federation, as one of the elements of the development of the logistics component of the republic's economy.

\section{Results}

Despite the national measures are taken in the development of the East Kazakhstan transportation and logistics complex, there are several issues:

- the unsatisfactory condition of fixed assets, the material base of the transport complex, high level of wear and tear of transport infrastructure objects, insufficient provision of settlements with regular passenger traffic (30 percent);

- illegal transportation of passengers and luggage, which affects the safety of passengers; low capacity of the railway line due to their "one way-track";

- absence of electrified railroad tracks, which significantly affects the cost of transportation; incomplete coverage of the entire territory of the region by rail;

- Insufficient development of air traffic in the region (no air traffic with remote settlements in the region);

- low quality of performed work and service rendered;

- low level of innovation and process automation, lack of developed transport and logistics centers, warehouses and terminals, insufficient number of qualified specialists.

The unbalanced location of the transport and communication network in the region impedes the development of a common economic space and the growth of population mobility. An industrially oriented network of railroads and freeways developed without taking into account the needs of the population. Its further optimization and partial reorientation are required, taking into account the prospects for territorial development, deployment of productive forces, and population settlement. Significant unevenness in the development of the transport network impedes economic development in the region. Some rural settlements do not have year-round transport links.

To improve the current state of transportation and logistics complex of the region it is necessary to solve a number of the following objectives:

- systematic development of all modes of transport and improvement of transport infrastructure;

- formation of an effective network of transport communications, renewal, and modernization of the fleet of vehicles;

- development of transport logistics, construction of large warehouse complexes, and improvement of infrastructure in key points of direct interaction between different modes of transport;

- research and implementation of the modern state regulation mechanisms of private transport market;

- education and training of qualified personnel of managerial and engineering-technical level;

- improvement of the local financial support system, attraction of investors and developers;

- improvement of the implementation mechanisms of R\&D developments; 
- use of innovative technologies in the transportation and logistics complex, provision with modern technologies and means of communication and information;

- regulation and improvement of tariff policy on transport;

- improvement of cargo and passenger transportation safety by all modes of transport;

- improving the quality of work performed and services provided by the transport system.

The mentioned measures should promote the development of the transportation and logistics complex of the region.

\section{References}

Aized T., Srai, J.S. (2020) Hierarchical Modelling of Last Mile logistic distribution system. International Journal Of Advanced Manufacturing Technology, 70, 1053-1061. https://doi: 10.1007/ s00170-013-5349-3

Blyde, J., Molina, D. (2015) Logistic Infrastructure and the International Location of Fragmented Production. Journal of International Economics, 95 (2), 319-332. https://doi: 10.1016/j.jinteco.2014.11.010.

Diogo, A., Lima, P., de Mascarenhas, F. W., Frazzon, E. M. (2015) Simulation-Based Planning and Control of Transport Flows in Port Logistic Systems. Mathematical Problems In Engineering, 1, 1-12. https://doi: $10.1155 / 2015 / 862635$

Avtomobil'nyj transport. Oficial'nyj sajt akima Vostochno-Kazahstanskoj oblasti (2019) [Automobile transport: Official website of the akim of East Kazakhstan region]. Retrieved from: https://www.gov.kz/memleket/entities/akimvko/press/article/details/transport?lang=ru [in Russian].

Apattsev, V.I., Levin, S.B, Nikolashin, V.M. (2003), Logisticheskie transportno-gruzovye sistemy [Logistics transport and cargo systems]. Moscow: Academy Publishing [in Russian].

Gosudarstvennaya programma razvitiya infrastruktury "Nurly zhol" na 2020-2025 gody (2020), [State program of infrastructure development "Nurly Zhol" to 2020-2025 years]. Retrieved from: http://adilet.zan.kz/rus/docs/P1900001055 [in Russian].

Koichubaev, A.S. (2013) Formirovanie regional'nyh logisticheskih setej v prigranichnyh territoriyah Respubliki Kazahstan i Rossijskoj Federacii [Formation of regional logistics networks in the border territories of the Republic of Kazakhstan and the Russian Federation]. Omsk [in Russian].

Mozharova, V.V. (2011), Transport v Kazahstane: sovremennaya situaciya, problemy i perspektivy razvitiya [Transport in Kazakhstan: current situation, problems and development prospects]. Almaty: KAZISS under the President of the Republic of Kazakhstan Publishing House [in Russian].

Otchet po razvitiyu malogo i srednego predprinimatel'stva v Kazahstane za 2018 god v razreze regionov (2019) [Report on the development of small and medium-sized businesses in Kazakhstan for 2018 by region]. Retrieved from: https://atameken.kz/uploads/content/files/report_2018.pdf [in Russian].

Prognoz sotsial'no-ekonomicheskogo razvitiya Vostochno-Kazakhstanskoy oblasti na 2017-2021 (2017) [Forecast of socio-economic development of the East Kazakhstan region for 2017-2021]. Retrieved from: .http://www.akimvko.gov.kz/ru/ekonomika/ [in Russian].

Raimbekov, Zh.S. and Syzdykbaeva B.U. (2019), Transportno-logisticheskaya sistema Kazahstana: mekhanizm formirovaniya i razvitiya [Transport and logistics system of Kazakhstan: mechanism of formation and development]. Almaty [in Russian].

Razvitiye seti transportno-logisticheskikh tsentrov Kazakhstana (2017) [Development of a network of transport and logistics centers in Kazakhstan]. Retrieved from: https://almaty.atameken.kz/uploads/content/files/ [in Russian].

Rezer, S.M., Prokofieva, T.A., Goncharenko A.M. (2010), Mezhdunarodnye transportnye koridory: problemy formirovaniya i razvitiya [International transport corridors: problems of formation and development]. Moscow [in Russian].

Sabden, O. and Raimbekov, Zh.S. (2010), Logistika (Ekonomika i Upravlenie) [Logistics (Economics and management)]. Almaty: Ministry of education and science of the Republic of Kazakhstan Publishing House [in Russian].

Sergeev, M. (2015), Innovacionnye tekhnologii v logistike i upravlenii cepyami postavok [Innovative technologies in logistics and supply chain management]. Moscow: SCM Consulting [in Russian].

Sheikin, D. (2019) Transportnaya otrasl' Kazahstana [Transport industry of Kazakhstan]. Retrieved from: https://kursiv.kz/news/issledovaniya/2019-04/kak-razvivaetsya-transportnaya-otrasl-kazakhstana [in Russian].

Statistika transporta. Oficial'nyj sajt Komiteta po statistike Ministerstva nacional'noj ekonomiki Respubliki Kazahstan (2019) [Transport statistics. Official website of the statistics Committee of the Ministry of national economy of the Republic of Kazakhstan]. Retrieved from: https://stat.gov.kz/official/industry/18/statistic/6 [in Russian].

Suleimenov, T.B., Arpabekov, M.I., Kuanyshbaev, Zh.M. (2015), Transportnaya logistika [Transport logistics]. Almaty: Evero [in Russian].

Sushchestvuyushchie na territorii RK gruzovye terminaly AO Kedentransservis (2019) [Existing cargo terminals of JSC "Kedentransservice" on the territory of the Republic of Kazakhstan]. Retrieved from: http://portal.kazlogistics.kz/terminal/list_terminals/ [in Russian]. 


\title{
Э.С. Мадиярова, Л.Б. Габдуллина, А.Ж. Зейнуллина
}

\section{Шығыс Қазақстан облысының көлік-логистикалық кешенінің қазіргі жағдайы}

\section{Aндатnа}

Maқscambl: Шығыс Қазақстан облысының көлік-логистикалық кешенінің қазіргі жай-күйі мен даму басымдықтарын зерделеу.

Әдісі: Зерттеудің теориялық негізі көліктік-логистикалық кешенді дамыту мәселелері бойынша отандық және шетелдік ғалым-экономистердің шығармалары, Қазақстан Республикасының заңнамалық және нормативтік-құқықтық актілері болып табылады. Зерттеудің ақпараттық негізін Қазақстан Республикасы Экономика министрлігі Статистика комитетінің деректері мен авторлардың зерттеу нәтижелері құрайды. Зерттеудің әдіснамалық негізі экономикалық үдерістерді зерттеудің жүйелі тәсілі, абстрактілі-логикалық, экономикалық-статистикалық, монографиялық әдістері болып табылады.

Қорытынды: Мақалада Шығыс Қазақстан облысының және өңірдің көлік кешенінің әлеуметтікэкономикалық дамуын талдау нәтижелері келтірілген. Жүргізілген талдау Шығыс Қазақстан облысының көліклогистика кешенін дамытудың негізгі проблемаларын, оның ішінде тасымалдаушылардың шектеулі логистикалық және техникалық мүмкіндіктерін, инфрақұрылымның дамымағандығын, дамыған көліклогистика орталықтарында қойма, үй-жайлары мен терминалдардың болмауын, білікті мамандардың жетіспеушілігін, қызмет көрсету сапасының төмендігін анықтауға мүмкіндік берді.

Тұжырымдама: Шығыс Қазақстан облысының көлік-логистикалық кешеніне әсер ететін негізгі факторлар зерттелді. Жүргізілген зерттеу нәтижесінде өңірдің көлік-логистикалық кешенін дамыту бойынша басым шаралар, оның ішінде көлік логистикасын жаңғырту, ірі қойма кешендерін салу және өндірістік инфрақұрылымды жетілдіру, көлік коммуникацияларының тиімді желісін құру және көлік-логистикалық кешенде инновациялық технологияларды пайдалану ұсынылды.

Kiлm сөздер: көлік кешені, логистика, макроөңір, өңірлік экономика, көлік желісі, көлік тораптары, жүк терминалдары, транзит, сыртқы сауда, жүк және жолаушылар тасымалы.

\section{Э.С. Мадиярова, Л.Б. Габдуллина, А.Ж.Зейнуллина}

\section{Современное состояние транспортно-логистического комплекса Восточно-Казахстанской области}

\begin{abstract}
Аннотация
Цель: Изучение современного состояния и приоритетов развития транспортно-логистического комплекса Восточно-Казахстанской области.

Meтоды: Теоретической основой исследования являются произведения отечественных и зарубежных ученых-экономистов по проблемам развития транспортно-логистического комплекса, законодательные и нормативно-правовые акты Республики Казахстан. Информационную основу исследования составили данные Комитета по статистике Министерства экономики Республики Казахстан и результаты исследований авторов. Методологической основой исследования являются системный подход, абстрактно-логический, экономикостатистический, монографический методы изучения экономических процессов.

Результаты: В статье приводятся результаты анализа социально-экономического развития ВосточноКазахстанской области и транспортного комплекса региона. Проведенный анализ позволил выявить основные проблемы развития транспортно-логистического комплекса Восточно-Казахстанской области, в том числе ограниченные логистические и технические возможности перевозчиков, неразвитость инфраструктуры, отсутствие развитых транспортно-логистических центров, складских помещений и терминалов, недостаток квалифицированных специалистов, низкое качество обслуживания.

Bbводы: Изучены основные факторы, влияющие на транспортно-логистический комплекс ВосточноКазахстанской области. В результате проведенного исследования предложены приоритетные меры по развитию транспортно-логистического комплекса региона, в том числе модернизация транспортной логистики, строительство крупных складских комплексов и совершенствование производственной инфраструктуры, создание эффективной сети транспортных коммуникаций и использование инновационных технологий в транспортнологистическом комплексе.
\end{abstract}

Ключевые слова: транспортный комплекс, логистика, макрорегион, региональная экономика, транспортная сеть, транспортные узлы, грузовые терминалы, транзит, внешняя торговля, грузовые и пассажирские перевозки.

\section{References}

Aized T., Srai, J.S. (2020) Hierarchical Modelling of Last Mile logistic distribution system. International Journal Of Advanced Manufacturing Technology, 70, 1053-1061. https://doi: 10.1007/ s00170-013-5349-3

Blyde, J., Molina, D. (2015) Logistic Infrastructure and the International Location of Fragmented Production. Journal of International Economics, 95 (2), 319-332. https://doi: 10.1016/j.jinteco.2014.11.010. 
Diogo, A., Lima, P., de Mascarenhas, F. W., Frazzon, E. M. (2015) Simulation-Based Planning and Control of Transport Flows in Port Logistic Systems. Mathematical Problems In Engineering, 1, 1-12. https://doi: $10.1155 / 2015 / 862635$.

Автомобильный транспорт: Официальный сайт акима DRJ. - Режим доступа: https://www.gov.kz/memleket/entities/akimvko/press/article/details/transport? lang=ru

Апатцев В.И. Логистические транспортно-грузовые системы: учеб. для студ. высш. учеб. завед. / С.Б. Левин, В.М. Николашин и др. - М.: Изд. центр «Академия», 2003. - 304 с.

Государственная программа развития инфраструктуры «Нұрлы жол» на 2020-2025 годы. — Режим доступа: http://adilet.zan.kz/rus/docs/P1900001055

Койчубаев А.С. Формирование региональных логистических сетей в приграничных территориях Республики Казахстан и Российской Федерации: дис. ... канд. экон. наук. — Омск, 2013. - 215 с.

Можарова В. В. Транспорт в Казахстане: современная ситуация, проблемы и перспективы развития. - Алматы: КИСИ при Президенте РК, 2011. - 216 с.

Отчет по развитию малого и среднего предпринимательства в Казахстане за 2018 год в разрезе регионов. Режим доступа: https://atameken.kz/uploads/content/files/report_2018.pdf

Прогноз социально-экономического развития Восточно-Казахстанской области на 2017-2021 гг. — Режим доступа: http://www.akimvko.gov.kz/ru/ekonomika/

Раимбеков Ж.С. Транспортно-логистическая система Казахстана: механизм формирования и развития: моногр. / Ж.С. Раимбеков, Б.У. Сыздыкбаева - Алматы, 2019. - 352 с.

Развитие сети транспортно-логистических центров Казахстана. - Режим доступа: https://almaty.atameken.kz/uploads/content/files/Презентация\%20НПП\%2031_01_2017г.pdf.

Резер С.М. Международные транспортные коридоры: проблемы формирования и развития: моногр. / С.М. Резер, Т.А. Прокофьева, С.С. Гончаренко - М., 2010. - 189 с.

Сабден О. Логистика (экономика и управление): учеб. / О. Сабден, Ж.С. Раимбеков. - Алматы: ИЭ КН МОН РК, 2010. - $910 \mathrm{c}$.

Сергеев В.И. Инновационные технологии в логистике и управлении цепями поставок / В.И. Сергеев. - М.: ЭсСи-Эм Консалтинг, 2015. - 314 с.

Статистика транспорта. Официальный сайт Комитета по статистике Министерства национальной экономики Республики Казахстан. - Режим доступа: http://stat.gov.kz

Сулейменов Т.Б. Транспортная логистика: учеб. / Т.Б. Сулейменов, М.И. Арпабеков, Ж.М. Куанышбаев. Алматы: Эверо, 2015. - 351 с.

Существующе на территории РК грузовые терминалы АO «Кедентранссервис». — Режим доступа: http://portal.kazlogistics.kz/terminal/list_terminals/

Шейкин Д. Транспортная отрасль Казахстана / Д. Шейкин. - Режим доступа: https://kursiv.kz/news/issledovaniya/2019-04/kak-razvivaetsya-transportnaya-otrasl-kazakhstana 